\title{
PENGARUH INOVASI SUMBER DAYA PERUSAHAAN TERHADAP KEUNGGULAN BERSAING PADA PT. ADIRA DINAMIKA MULTI FINANCE CABANG KOTA PALOPO
}

\author{
Hikma Safitri ${ }^{1}$, Suhardi M. Anwar ${ }^{2}$, Muh. Yusuf $Q^{3}$ \\ Email: 1)hikma@gmail.com, ${ }^{2)}$ suhardi@ stiem.ac.id ${ }^{3)}$ yusufq@ stiem.ac.id \\ ${ }^{1,2)}$ Prodi Manajemen, Sekolah Tinggi Imu Ekonomi Muhammadiyah Palopo \\ ${ }^{3)}$ Prodi Ilmu Pembangunan, Sekolah Tinggi Imu Ekonomi Muhammadiyah Palopo
}

\begin{abstract}
Abstrak
Penelitian in bertujuan untuk inovasi sumber daya perusahaan terhadap keunggulan bersaing pada PT. adira dinamika multi finance cabang kota Palopo. Sebuah basis sumber daya perusahaan termasuk semua yang merupakan pengeluaran organisasi untuk kinerja kegiatan penambahan nilai Perusahaan perlu menyesuaikan diri dengan perkembangan pasar dan mereka butuhkan untuk membangun kekuatan dari basis sumber daya mereka dan aktivitas system, Inovasi produk sekarang dipandang sebagai factor perangsang bagi pertumbuhan ekonomi dan komponen utama dari keuntungan kompetitif, Tidak cukup yang lebih lama dengan variabel-variabel yang mempengaruhi pemasaran atau inovasi produk, penelitian baru-baru ini menunjukkan sifat hubungan atara keduafungsi. Penelitian ini bertujuan untuk mengetahui apakah Inovasi Sumber Daya Perusahaan berpengaruh terhadap keunggulan bersaing PT. Adira Dinamika Multi Finance Cabang Kota Palopo. Dengan menggunakan data primer yang diperoleh dari penyebaran kusioner kepada responden sebanyak 60 0rang. Dengan menggunakan analisis data melalui pendekatan kuantitatif dan menggunakan regresi sederhana untuk menguji data dengan menggunakan aplikasi spss versi 21 hipotesis. Hasil penelitian secara konstanta menunjukan bahwa inovasi sumber daya perusahaan berepengaruh signifikan terhadap keunggulan bersaing pada PT. Adira Dinamika Multi Finance Cabang Kota Palopo. Dengan kontribusi koefesien beta 21,349. Inovasi sumber daya perusahaan berpengaruh terhadap keunggulan bersaing PT. Adira Dinamika Multi Finance dengan kontribusi koefesien beta 0,400 dan hasil signifikan yaitu 0,000 yang lebih kecil dari tingkat signifikan yaitu 0,05 , yang artinya inovasi sumber daya perusahaan secara langsung berpengaruh signifikan terhadap keunggulan bersaing pada PT. Adira Dinamika Multi Finance cabang Kota Ppalopo.
\end{abstract}

\section{Kata kunci: Inovasi sumberdaya perusahaan, keunggulan bersaing}

\section{PENDAHULUAN}

Sumber daya adalah suatu nilai potensi yang dimiliki oleh suatu materi atau unsur tertentu dalam kehidupan. Sumber daya tidak selalu bersifat fisik, tetapi juga non-fisik (intangible). Sumber daya ada yang dapat berubah, baik menjadi semakin besar maupun hilang, dan ada pula sumber daya yang kekal (selalu tetap). Selain itu, dikenal pula istilah sumber daya yang dapat pulih atau terbarukan (renewableresources) dan sumber daya tak terbarukan (non-renewableresources). Sedangkan, Pengertian atau definisi Perusahaan ialah suatu tempat untuk melakukan kegiatan proses produksi barang atau jasa. Hal ini disebabkan karena ' kebutuhan ' manusia tidak bisa digunakan secara langsung dan harus melewati sebuah ' proses ' di suatu tempat, sehingga inti dari perusahaan ialah tempat melakukan proses sampai bisa langsung digunakan oleh manusia. Untuk menghasilkan barang siap konsumsi, perusahaan memerlukan bahan - bahan dan faktor pendukung lainnya, seperti bahan baku, bahan pembantu, peralatan dan tenaga kerja. Untuk memperoleh bahan baku dan bahan pembantu serta tenaga kerja dikeluarkan sejumlah biaya yang disebut biaya produksi. Menurut Nasution (2005: 40) Inovasi adalah konsep yang lebih luas yang membahas penerapan gagasan, produk atau proses yang baru. Inovasi juga didefinisiskan sebagai penerapan yang berhasil dari gagasan kreatif perusahaan. Inovasi pada intinya adalah aktivitas konseptualisasi, serta menyelesaikan masalah dengan membawa nilai ekonomis bagi perusahaan dan nilai social bagi masyarakat. Jadi inovasi berangkat dari suatu yang sudah ada sebelumnya, kemudian diberi nilai tambah. Inovasibermula dari hal yang tampak sepeleh dengan membuka mata dan telingamendengarkan aspirasi atau keluhan konsumen, karyawan, lingkungan dan masyarakat.

$\begin{array}{cccc}\text { Sumber daya } & \text { perusahaan adalah } & \text { sumber } \\ \text { utama } & \text { keunggulan perusahaan. Kunci } & \text { utama }\end{array}$


perumusan strategi pertimbangan utama dalam merumuskan strategi dan menjadi dasar bagi perusahaan untuk menetapkan identitasnya serta menjadi berbasis sumber daya adalah memahami hubungan antara sumber daya, keunggulan kompetitif, dan tingkat keunggulan, terutama memahami mekanisme cara untuk mempertahankan keunggulan kompetitif dalam jangka panjang. Keunggulan bersaing adalah sesuatu yang dicari oleh setiap perusahaan bahkan setiap produk dalam persaingan yang dimasukinya. Keunggggulan bersaing menjadi sangat penting ketika perusahaan memasuki pasar yang sangat kompetitif (Ferdinand, 2003:211). Keungggulan bersaing berkelanjutan adalah hasil dari sebuah formulasi dan implementasi strategi yang sesuai ("'better fit"), yang mengakar pada tiga dimensi praktek manajemen stratejik yaitu: pada keberhasilan dalam upaya membangun basis bagi kompetisi, cara untuk kompetisi, serta pengelolaan arena kompetisi yang superior. Sebagai basis untuk kompetisi ia mengakar pada pemilihan asset yang tepat, pendayagunaan kompetensi dan kapabilitas yang sesuai. Hubungannya dengan cara bersaing akan merujuk pada pemilihan strategi-strategi fungsional, keputusan strategi serta implementasinya. Arena kompetisi menunjukkan dimensi produk, pasar, dan pesaing (Aaker, dalam Ferdinand 2003,p143). Aspekaspek dasar dan keunggulan bersaing yang berkelanjutan seperti yang disajikan dalam literature manajemen stratejik (Hall, 2001 dalam Ferdinand 2000:61) adalah sustainability dari atribut-atribut kunci sebuah produk dan durabilitas dari pada superioritas sumber daya intangible atas apa yang dimiliki pesaing keunggulan bersaing yang berkelanjutan dapat dirumuskan dari dimensi-dimensi durabilitas (daya tahan yang lama), imitabilitas (tingkat kesulitan untuk ditiru), serta tingkat kemudahan untuk menyamai asset-aset yang dimiliki oleh perusahaan. Bukti-bukti yang ada menunjukkan bahwa keunggulan kompetitiflah dan bukannya lingkungan eksternal yang menjadi sumber utama perbedaan keunggulan antar-perusahaan yang memusatkan perhatiannya pada sumber-sumber keunggulan kompetitif. Pengamatan yang lebih mendalam menunjukkan bahwa kekuatan pasar juga berbasis pada sumber-sumber daya perusahaan. Syarat fundamental kekuatan pasar adalah adanya batasanbatasan masuk. Batasan-batasan masuk ini didasarkan pada skala ekonomi hak paten, keunggulan pengalaman, reputasi merek, atau sumber-sumber daya lain yang dimiliki oleh perusahaan yang berhak tetapi pihak-pihak lain yang ingin ikut serta hanya dapat memperolehnya dalam jangka waktu lama atau dengan imbalan biaya yang mahal. Sesuai dengan latar belakan yang ada di atas menunjukan rumusan masalah sebagai berikut "Apakah Inovasi Sumber Daya Perusahaan berpengaruh terhadap keunggulan bersaing" PT.Adira Dinamika Multi Finance Cabang Kota Palopo. Sedangkan tujuan penelitian ini yaitu untuk mengetahui apakah Inovasi Sumber Daya
Perusahaan berpengaruh terhadap keunggulan bersaing PT. Adira Dinamika Multi Finance Cabang Kota Palopo

\section{TINJAUAN PUSTAKA}

\section{Inovasi Sumber Daya Perusahaan}

Inovasi merupakan salah satu jaminan untuk perusahaan atau organisasi dalam meningkatkan daya saingnya. Berbagai indikator menunjukkan bahwa ketertinggalan dalam inovasi menyebabkan sebuah produk tertinggal jaman atau kalah dalam persaingan yang ada. Tetapi bagaimana menyikapi dan mengantisipasi ketertinggalan tersebut melalui sebuah inovasi bukanlah suatu jawaban yang sederhana dan mudah. Peran inovasi dalam mendongkrak kinerja usaha meliputi seluruh aspek penting yang bisa memberikan nilai tambah pada daya saing perusahaan: proses, produk, pasar, manajemen, dan sebagainya. Menurut Nasution (2005: 40) Inovasi adalah konsep yang lebih luas yang membahas penerapan gagasan, produk atau proses yang baru. Inovasi juga didefinisiskan sebagai penerapan yang berhasil dari gagasan kreatif perusahaan. Inovasi pada intinya adalah aktivitas konseptualisasi, serta idemenyelesaikan masalah dengan membawa nilai ekonomis bagi perusahaan dan nilai social bagi masyarakat. Jadi inovasi berangkat darisuatu yang sudah ada sebelumnya, kemudian diberi nilai tambah. Inovasibermula dari hal yang tampak sepeleh dengan membuka mata dan telingamendengarkan aspirasi atau keluhan konsumen, karyawan, lingkungan dan masyarakat. Subyek penerapan inovasi sendiri biasa individu,kelompok atau perusahaan. Artinya biasa terjadi dalam perusahaan ada individu atau kelompok yang sangat brilian dan inovatif. Tetapi yang ideal perusahaan menjadi tempat yang terlembagakan bagi orang-orang yang terkumpul untuk mengeksploitasi ide-ide baru.

\section{Keunggulan Bersaing}

Keunggulan bersaing adalah sesuatu yang dicari oleh setiap perusahaan bahkansetiap produk dalam persaingan yang dimasukinya. Keunggggulan bersaing menjadi sangat penting ketika perusahaan memasuki pasar yang sangat kompetitif (Ferdinand, 2003:211). Keungggulan bersaing berkelanjutan adalah hasil dari sebuahformulasi dan implementasi strategi yang sesuai ("'better fit"), yang mengakar pada tiga dimensi praktek manajemen stratejik yaitu: pada keberhasilan dalam upaya membangun basis bagi kompetisi, cara untuk kompetisi, serta pengelolaan arena kompetisi yang superior. Sebagai basis untuk kompetisi ia mengakar pada pemilihan asset yang tepat, pendayagunaan kompetensi dan kapabilitas yang sesuai. Hubungannya dengan cara bersaing akan merujuk pada pemilihan strategi-strategi fungsional, keputusan strategi serta implementasinya. Arena kompetisi menunjukkan dimensi produk, pasar, dan pesaing (Aaker, dalam Ferdinand 2003). 
Aspek-aspek dasar dan keunggulan bersaing yang berkelanjutan seperti yangdisajikan dalam literature manajemen stratejik (Hall, 2001 dalam Ferdinand 2000:61)adalah sustainability dari atribut-

\begin{tabular}{|c|c|c|c|c|c|c|}
\hline \multirow[t]{2}{*}{ Model } & & \multicolumn{2}{|c|}{$\begin{array}{l}\text { Unstandardized } \\
\text { Coefficients }\end{array}$} & \multirow[t]{2}{*}{$\begin{array}{l}\text { Standardized } \\
\text { Coefficients }\end{array}$} & \multirow[t]{2}{*}{$\mathrm{t}$} & \multirow[t]{2}{*}{ Sig. } \\
\hline & & B & $\begin{array}{l}\text { Std. } \\
\text { Error }\end{array}$ & & & \\
\hline 1 & (Constant) & 21,349 & 3,774 & & 5,656 &, 000 \\
\hline & $X$ & 400 & 093 & ,493 & 4,313 & ,000 \\
\hline
\end{tabular}

atribut kunci sebuah produk dan durabilitas daripada superioritas sumber daya intangible atas apa yang dimiliki pesaing keunggulanbersaing yang berkelanjutan dapat dirumuskan dari dimensi-dimensi durabilitas(daya tahan yang lama), imitabilitas (tingkat kesulitan untuk ditiru), serta tingkatkemudahan untuk menyamai asset-aset yang dimiliki oleh perusahaan. Bukti-buktiyang ada menunjukkan bahwa keunggulan kompetitiflah dan bukannya lingkunganeksternal yang menjadi sumber utama perbedaan keunggulan antarperusahaan yangmemusatkan perhatiannya pada sumber-sumber keunggulan kompetitif. Pengamatan yang lebih mendalam menunjukkan bahwa kekuatan pasar juga berbasis pada sumber-sumber daya perusahaan. Syarat fundamental kekuatan pasar adalah adanya batasan-batasan masuk. Batasan-batasan masuk ini didasarkan pada skala ekonomi hak paten, keunggulan pengalaman, reputasi merek, atau sumbersumber daya lainyang dimiliki oleh perusahaan yang berhak tetapi pihak-pihak lain yang ingin ikutserta hanya dapat memperolehnya dalam jangka waktu lama atau dengan imbalan biaya yang mahal.

\section{METODE}

Populasi Dalam penelitan ini adalah seluruh karyawan Perusahaan PT.Adira dinamika multi finance cabang palopo sejumlah 60 Orang. Untuk penentuan sampel digunakan teknik pengambilan sampel jenuh yaitu dimana keseluruhan dari populasi dijadikan sebagai sampel penelitian. Metode pengumpulan data dilaksanakan melalui wawancara yaitu tehnik pengumpulan data melalui proses tanya jawab dalam penelitian yang berlangsung secara lisan antara dua orang atau lebih bertatap muka mendengarkan secara langsung informasi-informasi atau keterangan-keterangan lisan melalui dialog langsung anatara peneliti dengan para informan. Kemudian teknik pengumpulan data yang digunakan dalam penelitian ini adalah teknik pengumpulan data dengan menggunakan kuesioner. Kuesioner adalah teknik pengumpulan data yang dilakukan dengan cara memberi seperangkat pertanyaan atau pernyataan tertulis kepada responden untuk dijawab. Kuesioner merupakan teknik pengumpulan data yang efisien bila peneliti tahu dengan pasti variabel yang akan diukur dan tahu apa yang bisa diharapkan dari responden. Populasi Dalam penelitan ini adalah seluruh karyawan Perusahaan PT.Adira dinamika multi finance cabang palopo sejumlah 60 0rang.sekaligus menjadi sampel dalam penelitian ini. Adapaun metode analisis yang digunakan yaitu regresi sederhana.

\section{HASIL DAN PEMBAHASAN}

Analisis regresi dilakukan untuk mengetahui pengaruh antara variabl independen dengan variabel dependen. Dalam hal ini analisis yang digunagan untuk mengetahui pengaruh diantara dua variabel yaitu analisis regresi sederhana,dapat dilihat sebagai berikut.

\section{Tabel 1. Regresi Linear Sederhana}

Dari tabel diatas dapat disusun pesamaan regresi linier sederhana sebagai berikut:

$\mathrm{Y}=21,349-0,400$

Berdasarkan tabel diatas diperolh hasil persamaan regresi sederhana pada penelitian ini sebagai berikut :

1) Nilai konstanta sebesar 21,349 dapat diartikan bahwa apabila variabel bebas di anggap konstanta (inovasi sumber daya perusahaan $=0$ ) maka permintaan kredit akan mempunyai nilai sebesar 21,349 .

2) Koefisien regresi inovasi sumber daya perusahaan sebesar 0, 400 menggambarkan apabila variable inovasi sumber daya perusahaan (x1) meningkat sebesar 0,400 poin, maka akan mengakibatkan peningkatan pada keunggulan bersaing sebesar satu- satuan.

\section{Uji hipotesis}

Hasil analisis dan pengujian hipotesis dijelaskan sebagai berikut :

\section{Koefisien Determinasi}

Tabel 2. Koefisien Determinasi

\begin{tabular}{|l|r|r|r|r|}
\hline Model & R & R Square & $\begin{array}{c}\text { Adjusted } \\
\text { R Square }\end{array}$ & $\begin{array}{c}\text { Std. Error of the } \\
\text { Estimate }\end{array}$ \\
\hline 1 &, $493^{\mathrm{a}}$ &, 243 &, 230 & 3,139 \\
\hline
\end{tabular}

Sumber : Data Primer, 2017.

Berdasarkan tampilan SPSS model summary diperoleh hasil bahwa nilai adjusted $\mathrm{R}$ square sebesar 0,230 hal ini berarti $2,3 \%$ variasi keunggulan bersaing dapat dijelaskan dari variabel inovasi sumber daya perusahaan. Sedangkan sisanya $97.70 \%$ dijelaskan oleh sebab-sebab lain diluar model. Koefisien determinasi (adjusted Rsquare) antara inovasi sumber daya perusahaan terhadap keunggulan bersiang adalah sebesar 0,230 hal ini menunjukkan bahwa kemampuan inovasi sumber daya perusahaan terhadap keunggulan bersaing termasuk kuat dalam menerangkan keunggulan bersaing.

\section{Uji F}

Berdasarka $\mathrm{Uji}$ - F diperoleh hasil pengaruh secara bersama antara variabel independen inovasi sumber daya perusahaan terhadap pengaruh variabel dependen keunggulan bersaing pada tabel di bawa ini: 
Tabel 3. Uji F

\begin{tabular}{|rl|r|r|r|r|r|}
\hline Model & & $\begin{array}{c}\text { Sum of } \\
\text { Squares }\end{array}$ & df & $\begin{array}{c}\text { Mean } \\
\text { Square }\end{array}$ & F & Sig. \\
\hline \multirow{2}{*}{1} & Regression & 183,309 & 1 & 183,309 & 18,600 &, $000^{\mathrm{b}}$ \\
& Residual & 571,624 & 58 & 9,856 & & \\
& Total & 754,933 & 59 & & & \\
\hline
\end{tabular}

Sumber : Data Primer, 2017.

Berdasarkan Uji - F diperoleh hasil bahwa nilai $\mathrm{F}$ hitung sebesar 18.600 dengan tingkat signifikan 0,000. Karena tingkat signifikasi lebih kecil dari 0,05, maka model regresi dapat digunakan untuk memprediksi variabel independen inovasi sumber daya perusahaan berpengaruh terhadap variabel dependen keunggulan brsaing.

Uji t

Sementara itu secara parsial pengaruh dari variabel inovasi sumber daya perusahaan $(\mathrm{x})$ terhadap keunggulan bersaing (y) dapat dilihat pada tabel berikut:

Tabel 3. Uji F

\begin{tabular}{|c|c|c|c|c|c|c|}
\hline \multirow[t]{2}{*}{ Model } & & \multicolumn{2}{|c|}{$\begin{array}{l}\text { Unstandardized } \\
\text { Coefficients }\end{array}$} & \multirow[t]{2}{*}{$\begin{array}{l}\text { Standardized } \\
\text { Coefficients }\end{array}$} & \multirow[t]{2}{*}{$\mathrm{T}$} & \multirow[t]{2}{*}{ Sig. } \\
\hline & & B & $\begin{array}{l}\text { Std. } \\
\text { Error }\end{array}$ & & & \\
\hline 1 & (Constant) & 21,349 & 3,774 & & 5,656 &, 000 \\
\hline & $X$ & ,400 & ,093 & ,493 & 4,313 &, 000 \\
\hline
\end{tabular}

Berdasarkan Uji - $\mathrm{t}$ diperoleh hasil bahwa nilai $\mathrm{T}$ hitung sebesar 5,656dengan nilai signifikan 0,000, yang menjelaskan bahwa nilai signifikanlebih kecil dari pada tingkat signifikansi yaitu 0,05 yang berarti hipotesis diterima. Dengan demikian dapat disimpulkan bahwa variabel inovasi sumber daya perusahaan berpengaruh signifikan terhadap keunggulan bersaing. Hasil pengujian terhadap hipotesi menunjukkan bahwa variabe inovasi sumber daya perusahaan berpengaruh signifikan terhadap keunggulanbersaingdengan tingkat signifikan 0,000 karena dibawa tingkat signifikan 0,05 maka hipotesis diterima.

\section{Pembahasan}

Koefisien determinasi (adjusted Rsquare) antara inovasi sumber daya perusahaan terhadap keunggulan bersiang adalah sebesar 0,230 hal ini menunjukkan bahwa kemampuan inovasi sumber daya perusahaan terhadap keunggulan bersaing termasuk kuat dalam menerangkan keunggulan bersaing. Berdasarkan Uji t diperoleh hasil bahwa nilai t hitung sebesar 5,656 dengan nilai signifikan 0,000, yang menjelaskan bahwa nilai signifikan lebih kecil dari pada tingkat signifikansi yaitu 0,05 yang berarti hipotesis diterima. Dengan demikian dapat disimpulkan bahwa varia bel inovasi sumber daya perusahaan berpengaruh signifikan terhadap keunggulan bersaing . Berdasarkan Uji - F diperoleh hasil bahwa nilai $\mathrm{F}$ hitung sebesar 18.600 dengan tingkat signifikan 0,000. Karena tingkat signifikasi lebih kecil dari 0,05 , maka model regresi dapat digunakan untuk memprediksi variabel independen inovasi sumber daya perusahaan berpengaruh terhadap variabel dependen keunggulan bersaing.

\section{PENUTUP}

Simpulan

Berdasarkan analisis regresi sederhana baik secara bersama- sama maupun secara persial dihasilkan bahwa inovasi sumber daya perusahaan berpengaruh terhadap keunggulan bersaing pada PT. Adira dinamika multi finance Kota Palopo.

Saran

Berdasarkan hasil-hasil penelitian dan uraianuraian di atas, maka penulis mencoba memberikan sumbangsi pemikiran demi perbaikan dan pengembangan wawasan dalam dunia kerja pada umumnya dan khususnya dalam bidang manajemen agar dapat lebih baik lagi dalam mengelola pekerjaan di kantor/perusahaan. Karena itu hendaknya 1) Dapat menggali potensi-potensi yang dimiliki oleh sumber daya yang ada di perusahaan; 2) dapat melihat peluang dan tantangan yang ada agar dapat mengembangkan potensi-potensi yang lebih optimal lagi; 3) dalam upaya untuk meningkatkan keunggulan brsaing PT. Adira Dinamika Multi Finance cabang Kota Palopo maka diharapkan pimpinan/manajer dan karyawannya agar dalam menjalankan aktifitasnya lebih meperhatikan inovasi sumber daya perusahaan untuk mencapai hasil lebih baik.

\section{DAFTAR PUSTAKA}

Abraham Carmel. (2004). Membangun Strategi Difrensiatif Melalui sumber Daya Potensial Perusahaan Untuk Mencapai Kunggulan Yang Bersaing Yang Berkelanjutan (Studi kasus pada Industri Jasa Pngecatan Di Semarang). Tesis Program Studi Magister Manajemen Universitas Dipenogoro Semarang.

Farisi,Raisan Al. (2013).Pengaruh Inovasi Dan Kreativitas Pengusaha Terhadap Keberhasilan Bisnis, Skripsi, Fakultas Pendidikan Ekonomi Dan Bisnis Universitas Pendidikan Indonesia,Bandung.

Ferdinand, A. 2003.Structural Equation Modeling dalam Penelitian Manajemen. Badan Penerbit Universitas Diponegoro. Semarang.

Grant, Robert M., (1991). The Resource Based Theory of Competitive Advantange :Implications for Strategy Formulation. California Managemen Review,Spring: $114-135$. 
Hurley, R.F and G.T.M. Hult, 1998. Innovation, Market Orientation and Organizational: an Integration with Empirical Investigation, Journal of Marketing, Vol.62.

Kotler, Philip. (2005). Manajemen Pemasaran. Jilid Satu. Edisi Kesebelas. Alih Bahasa Benyamin Molan. Jakarta : Indeks.

Kotler, Philip, dan Gary Armstrong. (2005). DasarDasar Pemasaran Jilid 2. (Bambang Sarwiji). Jakarta: Indeks.

Li, S., Ragu-Nathan,B., Ragu-Nathan, T.S. \& Subba Rao, S. (2006). "The Impact of Supply Chain Management Practise on Competitive Advantage and Organizational Performance," Omega, 34(1). 107 - 124 McDaniel, B.A., (2002), Enterpreneurship and Innovation: An Economic Approach,M.E. Shape, Inc, New York.

Learning Day George S. and Robin Wesnley. (2000). Assessing Advantage: A Framework for Diagnosing Competitive Superiority. Journal of Marketing, 52 (April), 1-2

Nasution, M. N., (2005). Manajemen Mutu Terpadu (Total Quality Management). Ghalia Indonesia, Bogor

Richard ., (2006). Manajemen: Edisi Ke Lima. Jakarta: Erlangga.

Thatte, A.A. (2007). Competitive Advantage of a Firm through Supply Chain Responsiveness and SCM Practices. Unpublished dissertation, The University of Toledo.

Wahyono. (2002). "Orientasi Pasar dan Inovasi: Pengaruhnya Terhadap Kinerja Pemasaran". Jurnal Sains Pemasaran Indonesia. Vol.1,No.1,Mei.

Wiratmo, Masykur. (2001). Pengantar Kewiraswastaan (Kerangka Dasar Memasuki Dunia Bisnis). Yogyakarta: BPFE-Yogyakarta 